\title{
The Importance of Environmental Materials in Indonesian Language Learning
}

\author{
Puja Andrilla/18016121 \\ Pujaandrilla49@gmail.com
}

Language is the main thing used by humans to achieve the goals and desires that have been planned, especially in the field of education. Language can be conveyed orally or in writing. Language is closely related to students in school. The attitude of a good student can be reflected in the speech acts of his language, favorite reading books and phrases written in words. Agree with Thahar (in Ramadhan et al 2018) that unconsciously, someone has gained a lot of knowledge, experience, glass appeal, and even knowledge from the results of his reading.

A student's writing ability depends on the language he uses. The language expressed through writing is influenced by the student's environment. Writing is a difficult activity for students, made difficult by the addition of options for using the language that must be precise and correct. According to Sukma et al (2015) what can be done to involve students in finding sources in writing is to facilitate students to interact with the environment, so that students can actively participate in protecting the environment. Writing activities can indirectly drain the contents of the head for students. This is because the learning environment and the daily environment of students do not support students to think openly.

According to Sukma et al (2020) the purpose of environmental education is to provide a positive view of students on how to respond to the environment well, and increase knowledge of nature. With the environmental material, the mind and students' concern for the environment will increase. The application of environmental materials provides many benefits for students and the environment around students. Nkwetisma (in Ramadhan et al, 2019) also revealed that environmental education is a conscious concerted effort to teach or attract human attention about how the natural environment functions and how the natural environment functions and how this can manage and protect that nature.

An effective way to make it easier for students to write is by applying environmental materials to Indonesian language learning in schools. According to Ramadhan et al, (2018) the 
use of an environmental approach in learning to write is proven to improve students' writing skills. The application of environmental materials to Indonesian language learning can make students understand their surroundings. The activity of understanding and observing the environment can make students think so that they come up with ideas that are outlined in writing. Teacher is an important factor to increase the willingness and motivation of students to be enthusiastic in learning to write. Agree with the statement of Sukma (2013) which states that teachers and lecturers have an important role in innovative efforts in learning.

According to Ramadhan (2019) environmental education can help students rethink the relationship between humans and the environment, understand the environment, become aware of environmental problems, and consider environmental problems related to life. Environmental materials can indirectly lead students to think about and observe their surroundings. Environmental awareness can make students aware of their concern for the environment. It is predicted that environmental materials applied in Indonesian language learning will provide great benefits for both sides, for students and the environment.

Environmental materials not only have an impact on students 'academics but also change students' attitudes and personality. This is also supported by the opinion of Erdogan, Wang, Uyar, Yumusak, and Akman (in Ramadan et al, 2019) that it is necessary to develop individuals who are aware and responsible for the environment to overcome this so that environmental problems are sustainable and a better quality of life. good. All will be realized if environmental material can be applied to learning in schools, especially in Indonesian subjects.

Environmental materials in Indonesian language learning are very useful, especially for improving students' writing skills. According to Sukma et al (2017) the fact is that learning and writing have not been able to improve the character of students, this is because of the different backgrounds of students. The importance of environmental material is related to learning and the student environment. Supported by the opinion of Lacobs G. M and Cates (in Ramadhan et al, (2019), stated that environmental education is to make students participate in protecting the environment. Teachers have an important role to foster students' awareness of the environment by providing and explaining material about the environment. 
The application of environmental materials in learning must be student-oriented. Agree with that Sutopo (in Sukma) revealed that student-oriented learning has characteristics, namely: (1) placing students as learning subjects who must actively develop their drills, (2) learning is active, participatory, and collaborative and thoroughly combines aspects specific and generic life skills, (3) the teacher functions as a learning facilitator and manager, (4) according to the principles of thorough learning and talent development, each student must be given the opportunity to achieve goals according to their ability and learning speed, (5) comprehensive, concerning the results and the learning process. Learning like this can help students more easily absorb and understand environmental material in learning.

Based on the questionnaire that the author distributes about " The Importance of Environmental Materials in Indonesian Language Learning" to Padang State University students in semester 1 and semester 5, Padang State Polytechnic students in semester 5, Riau University students in semester 5, STKIP Pharmacy students, students, entrepreneurs and housewives . Of the total 37 respondents who participated in filling out the questionnaire, 27 respondents were more dominant and 10 male respondents with a percentage of $73 \%$ female, $27 \%$ male. The first statement "Environmental materials in Indonesian language learning have a positive impact on students" 64.9\% strongly agree, 35.1 agree, $0 \%$ disagree and $0 \%$ disagree. The second statement "Environmental material in Indonesian language learning is very useful for overcoming student difficulties in learning" 56.8\% agreed, $35.1 \%$ strongly agreed, $8.1 \%$ disagreed and $0 \%$ disagreed. The third statement "Cleaning the classroom before the learning process is carried out, so that students are more concentrated and comfortable while studying. It is one of the environmental learning materials that students have indirectly done. "48.6\% strongly agreed, 48.6 agreed, 2.8\% disagreed and $0 \%$ disagreed. Fourth Statement "The role of parents is very important to guide students to understand and practice learning materials about the environment" $48.6 \%$ strongly agreed, $45.9 \%$ agreed, 5.4\% disagreed and 0\% disagreed. The fifth statement "Environmental material is closely related to Indonesian language learning" $62.2 \%$ agreed, $35.1 \%$ strongly agreed, $2.7 \%$ disagreed and $0 \%$ disagreed. The sixth statement "Environmental materials can make students observe the surrounding environment and relate it to learning Indonesian" $70.3 \%$ agreed and $29.7 \%$ strongly agreed, $0 \%$ disagreed and $0 \%$ disagreed. The seventh statement "In 
learning Indonesian, students are able to see changes that occur in students before and after studying environmental material" 64.9\% agreed, 32.4\% strongly agreed, $2.7 \%$ disagreed and $0 \%$ said they did not. agree. The eighth statement "Environmental materials can be used as media by teachers in Indonesian language learning" 59.5\% strongly agree, 37.8\% agree, 2.7\% disagree and $0 \%$ disagree. The ninth statement "Environmental materials in Indonesian language learning can change students' mindset about the environment" 51.4\% agreed, $45.9 \%$ strongly agreed, $2.7 \%$ disagreed and $0 \%$ disagreed. The tenth statement "Teachers must play an active role in explaining to students the importance of environmental materials" $54.1 \%$ agreed, $45.9 \%$ strongly agreed, $0 \%$ disagreed and $0 \%$ disagreed.

Based on the results of distributing questionnaires that have been carried out, the authors conclude that environmental material in education has an important role in making students aware of the surrounding environment. Indirectly, the environment supports the improvement of students' skills both in writing skills, reading skills, speaking skills and listening skills. Environmental materials can help students to overcome difficulties when solving topics in Indonesian language learning, which mostly consists of text. Educational institutions play an important role in fostering insights about the environment to students and teachers play a role as facilitators in the process of developing environmental materials. 


\section{REFERENCE}

Ramadhan, Syahrul, Guci \& Nursaid. (2016). Korelasi penguasaan kosakata bidang lingkungan hidup dengan menulis karangan argumentasi tentang lingkungan hidup.Jurnal Pendidikan Bahasa dan Sastra Indonesia 5(2).

Ramadhan, Syahrul, Sukma \& Indriyani. (2019) Environmental education and disaster mitigation through language learning. Earth and Environmental Science 314.

Ramadhan, Syahrul. (2008) Representasi kesantunan tindak tutur berbahasa Indonesia dalam pembelajaran di kelas ( Kajian Etnografi Komunikasi). Diksi 15(2).

Ramadhan, Syahrul, Sari \& Rasyid. (2018) Hubungan antara keterampilan membaca pemahaman dengan keterampilan menulis teks laporan hasil observasi siswa kelas $X$ SMK Negeri 3 Padang. Jurnal Pendidikan Bahasa dan Sastra Indonesia, 7 (3).

Ramadhan, Syahrul, Halawa \& Gani (2018) Kesantunan Berbahasa Indonesia Dalam Tindak Tutur Melarang Dan Mengkritik Pada Tujuh Etnis.Lingua XV (2)

Ramadhan, Rozana \& Basri (2018) Kontribusi Motivasi Belajar Dan Penguasaan Kosakata Terhadap Keterampilan Menulis Teks Eksposisi Siswa Sma.Lingua XIV (1).

Sukma, Elfia. (2017). Pembelajaran sastra yang intergratif berbasis kompetensi. Jurnal UNY. International Seminars On Language And Arts (ISLA).

Sukma, Elfia., Mahyudin, Rahmatina \& Suriani. (2018) Problem In Oral Language Teaching In Primary School. Advances in Social Science, Education and Humanities Research, volume 301

Sukma, Elfia. dan Mansur Lubis. (2013). Pembelajaran menulis pantun secara integrative berbasis lesson study. Jurnal Pendidikan Bahasa dan Sastra. 14(1).

Sukma, Elfia. (2015). Peningkatan keterampilan menulis dengan model PAKEM melalui teknik menjadi wartawan junior di sekolah dasar. Jurnal Pendidikan Sains dan Kemanusiaan. $8(1)$ 


\section{ATTACHMENT}

TABLE 1

Questionnaire on the Relationship of Indonesian Language Learning with the Environment

\begin{tabular}{|c|c|c|c|c|c|}
\hline No & Pertanyaan & SS & $\mathbf{S}$ & $\mathbf{K S}$ & TS \\
\hline 1. & $\begin{array}{l}\text { Environmental materials in Indonesian language } \\
\text { learning have a positive impact on students. }\end{array}$ & $64,9 \%$ & $35,1 \%$ & - & - \\
\hline 2. & $\begin{array}{l}\text { Environmental materials in Indonesian language } \\
\text { learning are very useful for overcoming student } \\
\text { difficulties in learning. }\end{array}$ & $35,1 \%$ & $56,8 \%$ & $\begin{array}{l}8,1 \\
\%\end{array}$ & - \\
\hline 3. & $\begin{array}{l}\text { Cleaning the class before the learning process is } \\
\text { carried out, so that students are more concentrated and } \\
\text { comfortable while studying. It is one of the } \\
\text { environmental learning materials that students have } \\
\text { indirectly done. }\end{array}$ & 48,6 & $48,6 \%$ & $\begin{array}{l}2,8 \\
\%\end{array}$ & - \\
\hline 4. & $\begin{array}{l}\text { The role of parents is very important to guide students } \\
\text { to understand and practice learning materials about the } \\
\text { environment. }\end{array}$ & $48,6 \%$ & $45,9 \%$ & $\begin{array}{l}5,4 \\
\%\end{array}$ & - \\
\hline 5. & $\begin{array}{l}\text { Environmental materials are closely related to } \\
\text { Indonesian language learning. }\end{array}$ & $35,1 \%$ & $62,2 \%$ & $\begin{array}{l}2,7 \\
\%\end{array}$ & - \\
\hline 6. & $\begin{array}{l}\text { Environmental materials can make students observe } \\
\text { the surrounding environment and relate it to learning } \\
\text { Indonesian }\end{array}$ & $29,7 \%$ & $70,3 \%$ & - & - \\
\hline 7. & $\begin{array}{l}\text { In learning Indonesian, students are able to see the } \\
\text { changes that occur in students before and after } \\
\text { studying environmental material. }\end{array}$ & $32,4 \%$ & $64,9 \%$ & $\begin{array}{l}2,7 \\
\%\end{array}$ & - \\
\hline 8. & $\begin{array}{l}\text { Environmental materials can be used as media by } \\
\text { teachers in Indonesian language learning }\end{array}$ & $59,5 \%$ & $37,8 \%$ & $\begin{array}{l}2,7 \\
\%\end{array}$ & - \\
\hline 9. & $\begin{array}{l}\text { Environmental material in Indonesian language } \\
\text { learning can change the mindset of students about the } \\
\text { environment. }\end{array}$ & $45,9 \%$ & $51,4 \%$ & $\begin{array}{l}2,7 \\
\%\end{array}$ & - \\
\hline 10. & $\begin{array}{l}\text { Teachers must play an active role to explain to students } \\
\text { the importance of environmental materials. }\end{array}$ & $45,9 \%$ & $54,1 \%$ & - & - \\
\hline
\end{tabular}

The number of respondents was 37 people consisting of Padang State University Students, Padang State Polytechnic Students, Riau University Students, Pharmacy STKIP Students, Students of SMK Negeri 2 Pariaman, Entrepreneurs and Housewives.

Note :

SA : Strongly Agree

A : Agreed

D : Disagree

SD : Strongly Disagree 